\title{
Urban Networks in Latium
}

ABSTRACT Rome's hinterland, Latium, has long been a focus of research. It offers a remarkably rich set of information, archaeological, epigraphical, and literary, and especially for the period $200 \mathrm{BC}$ to AD 200. We can see a densely settled countryside with a scatter of urbanized settlements, and we can trace links between them and repetitive cultural behaviours. This paper presents the potential of a new database, combining three major surveys, and relates this first to the model of the globalized countryside, and then argues for the relevance of actor-network theory and assemblage theory. The intention is to encourage a renewed collaborative effort to understand 'urbanity' at a regional level, in central Italy and elsewhere.

KEYWORDS Rome; Latium; urbanity; globalization; network theory.

\section{Acknowledgements and Funding Details}

This work was supported by the Danish National Research Foundation under the grant DNRF $119-$ Centre of Excellence for Urban Network Evolutions (UrbNet), and I am immensely grateful to Rubina Raja and colleagues for the invitation, and to the Leverhulme Trust for a major research fellowship during this period.

I have been very fortunate to participate in the Rome Hinterland Project, and also the British School at Rome's Segni project, from which I learnt a huge amount (Cifarelli and others 2019), and the Roman Hinterland Database Project.

Second, an important workshop organized by Eva Hagen, Marlen Termeer, and Michael Teichmann in 2013 on Landscape and Memory in Ancient Latium, a joint initiative between the Deutsches Archäologisches Institut and the Koninklijk Nederlands Instituut in Rome, brought an international group of early career researchers together for a series of talks and visits, and it was a great honour to be a part of it. Many of the participants, including E. Hagen, K. Kaderka, C. Moser, D. Miano, J. Seubers, M. Termeer, and M. Teichmann, have now produced significant theses and books, and part of this paper has reflected on some of this work. I am very grateful to the organizers for involving me in an extraordinary event.
Third, the work of UrbNet has introduced me to the idea of urban networks in a comparative framework. The nexus of lived experience and urbanity is also the focus of work as part of the DfG-funded project 'Religion and Urbanity: Reciprocal Formations' (FOR 2779), which has also been inspirational; <https://www.uni-erfurt.de/max-weber-kolleg/ forschungsgruppen-und-stellen/religion-and-urbanity/> [accessed April 2020].

Finally, whilst I remain responsible for any errors, I am grateful to the journal's reviewers, Rubina Raja, Søren Michael Sindbæk, Peter Attema, Tymon de Haas, Corinna Riva, David Nonnis, Federica Sulas, and Lieve Donnellan for comments and encouragement.

\section{Introduction: The Current State of Research}

Latium is a region of ancient Italy situated between the Tiber River and the Apennines, and the Monti Lepini and the marshes of the Pontine area, which were incorporated as Latium Adjectum. It was part of the Augustan Regio I, and its inhabitants, the Latins, were distinguished from the Etruscans to the north and the Oscan-Sabellic speaking peoples to the east and south by their language, Latin. The extension of the region north of the Tiber, as with modern Lazio, is the product of the development of the duchy of Rome as part of the Justinianic conquest in the sixth century AD. Geologically, it is dominated by the extinct volcanic Colli Albani, which also formed the plain that runs down to the Tyrrhenian coast. Politically and historically, the development of Rome, first as the pre-eminent settlement in the region, and then as a world power, had an immense impact on the political and economic development of the region. ${ }^{1}$

In fact, we are remarkably well informed as to the hinterland of one of the world's great metropoleis, and over a long period of time. Apart from

1 For good overall summaries, see Solin 1996; Cornell 2000; Moggetta 2014.

Christopher Smith (cjs6@st-and.ac.uk) is Professor of Ancient History at the University of St Andrews, and was Visiting Fellow at the Aarhus Centre for Urban Network Evolutions in 2019. 
abundant publications for over a century, if one couples the evidence for the area south of the Tiber with the results of the South Etruria Survey led by John Bryan Ward-Perkins from 1955 and the Tiber Valley Project, which the British School at Rome initiated as a restudy of the material in the late 1990s, one can map an extraordinary density of settlement over time (Potter 1979; Patterson, di Giuseppe, and Witcher forthcoming).

This wealth of material obviously reflects at some level the influence exerted by the city of Rome itself. There are relatively few cities in history which have been so dominant, and much work has been done on the extractive capacities of the city and the economic and demographic consequences for the neighbouring regions. ${ }^{2}$ As a laboratory for regional survey and analysis, Lazio is exceptional. This has given rise to the Rome Hinterland Database Project which will combine the Tiber Valley Project survey data with the results of two major and contiguous datasets from the Pontine Region Project and La Sapienza's Suburbium project. This will open the way for analysis of the survey data and the possible application of GIS modelling across the region. ${ }^{3}$

The prospects for archaeological synthesis therefore are strong; but we lack a strong theoretical model for understanding the nature of this geographical area. How might we best think of it in regional terms, as opposed to individual settlements?

Geographically, this paper will respect the ancient definition of Latium, omitting southern Etruria, modern northern Lazio. The chronological framework of this paper is limited to the period between roughly $200 \mathrm{BC}$ and $\mathrm{AD} 200$. Whatever our reservations around the terms urban and urbanization when used as an evolutionary marker of a specific socio-political stage, by this time, there are a number of settlements which have all the characteristics which are normally applied to urbanism. The question then becomes less a matter of how urban they are, and more about what it means to live in an urban society (Cornell and Lomas 1995).

This paper sets out to address this from three distinct angles. First, we will offer some macro-scale parameters from the various datasets we have for Latium. Second, we will place this evidence in the context of the powerful contemporary theoretical approach of globalization. Finally, we will return

2 Erdkamp 2001; recent, controversial general accounts by Temin 2012 and Kay 2014; survey articles on Rome in Erdkamp 2013.

3 <http://comparativesurveyarchaeology.org/> [accessed 1 April 2020]. In addition, the University of Rome La Sapienza is developing a database and accompanying atlas for Latium (Capanna and Carafa 2019). to the notion of networks, to argue for a combinatory method as a way of understanding Latium as a regional space and an urban ecology.

\section{Macrohistory: The Parameters of Urban Latium}

The heyday of the metropolis of Rome was between the end of the Second Punic War, at the beginning of the second century вС, and the end of the second century AD (Holleran and Claridge 2018). Rome was not seriously threatened by an enemy from outside, and the city was the object of intense building work and unparalleled imperial munificence.

How should we best characterize the impact of the city on its surroundings? A traditional account might focus on consumer-city models and emphasize the extractive power of a city of three-quarters of a million inhabitants, one which far surpassed any other city in Italy and which had few if any competitors anywhere in the world at the time or subsequently (Morley 1996, 2-3). However, Neville Morley (1996) showed that the model of an entirely parasitic city was not a wholly satisfactory theoretical solution for the distinctive problems of capitalism, and not necessarily applicable either to the ancient city. Each metropolis has an impact on its hinterland, but the nature of that impact varies over space and time between individual cases and within each case study.

In the case of Rome in the period discussed, whilst the city was almost entirely a consumer, it also had an empire on which to rely. Staples, especially grain, were taken care of by large-scale imports, leaving the immediate hinterland able to focus on intensive, market-oriented, specialised production of expensive perishables; fruit, certain vegetables, dairy products. ${ }^{4}$

Inevitably, this raises the issue of the development of villa agriculture, and the ways in which this form of production, heavily dependent on slavery, can be understood in the context of the central Italian economy. Who was benefitting from these villas? How did they operate in an overall economic structure? How rational and how scalable was villa economy (Becker and Terrenato 2012; Marzano and Métraux 2018)?

These are questions which have occupied scholarship for some time, and not only in central Italy. However, the central Italian situation has the added complexity of the numbers of imperial villas, which

4 Morley 1996, 86; though see now Marzano 2013 for olive oil and wine. 
can be identified in the landscape, in a greater degree of concentration than elsewhere (De Franceschini 2005; Frizell and Klynne 2005; Marzano 2007; Venditti 2011; Angelelli 2016). So we have to deal with questions of villas sustaining market demand, however limited they may have been by the slave mode of production, and the issue of how the villas of the emperors fed into this overall scheme. We also have to assess the condition of towns in the hinterland over this period, and the extent to which villa and town prosperity are causally linked.

To give some ideas of the scale of material we are dealing with, Annalisa Marzano catalogues 384 villas from Latium in her invaluable survey (2007). Most accounts, both ancient and modern, arrive at about forty or so towns. ${ }^{5}$ All the data points to high population density in the early empire, and Robert E. Witcher's cautious suggestion is that the suburbium, which he defines as the area up to $50 \mathrm{~km}$ from Rome, had at its early imperial peak about half of Rome's population, perhaps 350,000 people to Rome's 700,000. If one adds the 50 to $100 \mathrm{~km}$ zone as a further variable, the total in the suburbium may easily equal the total population in Rome (this includes the densely inhabited areas of northern Lazio) (Witcher 2005; 2008).

Witcher's densities of population suggest in the region of 60 persons $/ \mathrm{km}^{2}$ for the inner ring, and 42 persons $/ \mathrm{km}^{2}$ for the additional area between 50 and $100 \mathrm{~km}$ from Rome. However, as Witcher is well aware, these figures are only approximate averages. Peter Attema and Tymon de Haas (2011) for instance arrive at a population density closer to the higher figure when they extrapolated from the survey data for Antium and its hinterland, towards the south of the region. They argued that this reflected the close integration of Antium with Rome, through its harbour, the Via Appia, and the social ties between an area which had many maritime villas, imperial patronage, and eventually a Neronian colony, and which was also tied into the network of settlements in the plain and the Lepini Mountains beyond. ${ }^{6}$ It is evident from survey data that in most of the suburbium, population density increases with the growth of Rome in the first two centuries AD.

Assuming that we follow urbanization rates (the proportion of people in towns to people outside towns) and population densities inside towns of early modern times, that is in the order of 20 per cent of the population in towns with a density in the order of 180 inhabitants per urban hectare, we are prob-

5 Cornell 2000 and Bispham 2007 for discussion.

6 More generally Attema, de Haas, and Tol 2011. ably looking at dozens of settlements of between 5 and 10,000 people. ${ }^{7}$ There must have been several other smaller-scale settlements too, and we are just beginning to make sense of the category of minor centres as a key element in the network of the flow of goods and people. ${ }^{8}$

These towns are linked by a complex and sophisticated infrastructure. Roads are crucial, both the large Roman constructions from the fourth century BC onwards (Appia, 312 BC, Tiburtina c. 286 BC, Flaminia 220 BC, and also the Via Salaria and Via Gabina/Prenestina, which were of greater antiquity) but also local roads and connections, which remain patchily mapped (Laurence 2011; Quilici 1991), and bridges. ${ }^{9}$ Along the roads, there are a number of stations of one kind or another, some but not all of which develop into the later mansiones, and we also find collegia of muleteers for instance. ${ }^{10}$ Water supply can be traced to many of the towns and was clearly a significant aspect of the organization of town and villa life (Thomas and Wilson 1994; Purcell 1996; Wilson 2009).

Eric C. De Sena (2005) and Marzano (2013a) have convincingly shown that Lazio made a significant contribution in terms of wine, olive oil, and other comestibles. Moreover, the processes of creating the urban and villa network itself involved a wide range of productive activities from quarrying (Russell 2013) to tile and brick production (Graham 2006a; Cifarelli and Nonnis 2019), mosaics, ${ }^{11}$ and so forth, which then required their own infrastructure - for instance the production of charcoal (Veal 2013; 2017; Horden 2014). The productive landscape of Latium is clearly critically important for its own prosperity and one can imagine producing ever more detailed mapping of this through the opportunities offered by the major survey databases. We can already produce maps of certain indicative features such as kilns, mills, and so forth.

A truly environmental history of Latium, reflective of its resource opportunities, has yet to be written, but some of the material certainly exists. It would clearly show a highly variegated landscape, including the plains around Rome and in the Pontine region, the

\footnotetext{
7 De Ligt 2012; Pelgrom 2013 has a much higher density.

8 See De Francesco 2014; Keay and Millett 2016; Tol and others 2014 and Tol, de Haas, and Anastasia 2019 for vital economic role of minor centres.

9 Frezza 2012 for epigraphy.

10 France and Nelis-Clément 2014; Coarelli 2019; CIL (Corpus inscriptionum latinarum) VI. 9485 for muleteers on the Via Tiburtina, on which see Bjur and Frizell 2009; intriguing evidence from the Antonine itinerary, Graham 2006b; Talbert 2008; Bernard 2019.

11 Angelelli and Tortorella 2016, outlining a new corpus.
} 
Monti Lepini and the pre-Apennine Monti Lucretili, Monti Tiburtini, and Monti Prenestini, and the Alban Hills. It is also important to note the significance of the façade maritime, which operated across a continuum of productive pesciculture, port activity, through to grandiose luxury villas. ${ }^{12}$ One key aspect of a regional approach would be to understand more thoroughly the kind of relationship between coast and inland, cutting across the north-west to southeast road network.

Understanding mobility is key to going beyond the static cartographic representation. How many people were mobile and for what purposes? Despite all the recent attention to mobility (De Ligt and Tacoma 2016; Tacoma 2016; Isayev 2017), short-distance intra-communal mobility is extremely difficult to track, but the degree of facilitation which is evident in the Latin countryside is a strong proxy for the assumption that this was common and frequent. ${ }^{13}$ Markets were frequent and important (Frayn 1993; Storchi Marino 2000), which of course also feeds back into our understanding of the regional economy.

Almost every aspect of this section merits further study and definition. My intention has been primarily to show how densely occupied, and how intensively used, the Latin landscape must have been. This causes us to inquire as to how profoundly known this landscape must have been, the ways in which it was perceived, apprehended, and described, and how we should translate that in terms of urban networks. How then can we make sense of this landscape? One recent approach has been to think in terms of globalization, as a way of explaining the impact of intensification, and recently this has been applied to the suburbium. This is the subject therefore of our next section.

\section{The Globalization Thesis}

The relationship of the suburbium to two of the most successful arguments in Roman imperial history over recent years, Romanization and globalization, is intriguing. The Latins spoke the same language as the Romans, worshipped more or less the same gods in more or less the same way. Their conquest moment was early and arguably led quickly to the participation of Latins in Roman politics. ${ }^{14}$ There is a sort of mutual expansion, and if there was no question that Rome had won in the fourth cen-

12 Lafon 2001; on the maritime aspect more generally Marzano 2013 b.

13 See Grey and others 2015 for a similar argument in medieval Tuscany.

14 Salomies 1996 for Latins in the senate. tury, everything we have seen so far indicates that Rome was Latinized as much as the Latins were Romanized (Terrenato 2019; Cifarelli, Gatti, and Palombi 2019). The Romanization debate has therefore largely passed by Latium.

As the Romanization debate has proceeded, and to some extent faded (Keay and Terrenato 2001; Aberson and others 2016), the notion that globalization might be useful for explaining aspects of Roman imperial development has come to the fore (Pitts and Versluys 2015; Hodos 2017). Here the suburbium is much closer to the heart of the argument. From one point of view, the towns of Latium are clearly central to the notion of a standardized cultural package (Wallace-Hadrill 2008), and it is also clear that from the second century $\mathrm{BC}$ onwards they provided an important part of the traders and business infrastructure that sustained the globalizing empire. ${ }^{15}$

So we can trace the flow of Latins from their towns into the Mediterranean and back; but what about the countryside? We can take for instance the recent demonstration of the role of Fondi in the wine trade with southern France to stand for other engagements of the rural productive landscape with the wider Mediterranean. A wreck off Hyères, Var, near Marseilles reveals a cargo of hundreds of amphorae from two workshops at San Biagio and San Anastasia near Fondi in the first century ВС, shipping the famous Caecubum and Fundanum wines. ${ }^{16}$ Many are stamped by P. Veueius Papus, who clearly owned the atelier and the vineyard, and whose amphorae have also been found in Morocco (Boube 1985-1986). The stamping system reveals the mechanisms of tracing cargoes, presumably for tax purposes; but the system will obviously only work because of the port and harbour system of coastal Latium. Do we regard this as part of the urban or the rural economy of Latium?

In this context Witcher's (2017) use of the notion of the globalized countryside, championed by Woods (2007; 2009), is applicable to our case study. The problem which Michael Woods was addressing was the place of the countryside within globalization discourses, which tend to be dominated by cities, and which therefore leave the countryside as 'acted upon'. The specifics of the rural experience are to an extent discounted. Woods's aim therefore was to identify a theoretical framework for the globalized countryside which made it possible to include that rural experience.

15 See, for instance, Hasenohr 2007; Coarelli 2016 for Delos.

16 Hesnard 2012; see Di Fazio 2006 for Fondi, and Tchernia 1986; Woolf 1992; Marzano 2013b for wine trade and economy. 
Witcher summarizes the ten distinct categories as follows:

1. Elongation of commodity chains and increased dependency on the consumption of imported commodities.

2. Externalization of property ownership and investment.

3. Social power and economy are monopolized by fewer people and institutions.

4. The scaling up of social and political authority beyond local reach.

5. Enhanced social polarization whereby the enterprising few have new opportunities to amass wealth but the majority do not.

6. The global countryside is a supplier - and user — of migrant labour.

7. The global countryside is inscribed with the marks of globalization in the form of environmental degradation including deforestation, erosion, and the expansion of pastoral landscapes.

8. The global countryside involves a discursive construction of Nature.

9. The global countryside is used less for agricultural production and increasingly as the focus of leisure and tourism.

10. The 'global countryside' is contested.

Witcher has shown how all Woods's categories can apply to the Roman imperial landscape, with relevant adjustments. By comparing the suburbium with the more rugged and distant region of the Apennine Abruzzo, Witcher $(2017,49)$ is able to demonstrate that 'the cultural distance between rural and urban was much greater in the newly and thinly urbanized region of Samnium than it was in the long and densely urbanized suburbium.

However, it is not clear that the distinct criteria outlined by either Woods or Witcher are actually specifically relatable to rural or urban contexts. They can certainly be illustrated in rural contexts, but at the same time one could adapt them with little difficulty to the urban. This is not an objection to the concept, which serves to draw the rural into a discourse which has been too heavily focused on urban centres. However, one could also rewrite the claims for the globalized countryside as claims for a continuum of rural and urban experience. Elongated supply chains, concentration of power, environmental degradation, and the discursive construction of a city/countryside divide are experiences shared and described across the metropolis to hinterland boundary.
Another point of potential weakness is the relationship between the higher-order theory and individual elements of evidence which can be brought to bear. So we can talk about the widespread use of Samian ware as an illustration of the consumption of imported goods, and of standardization, and this whole subject was brilliantly explored by Andrew Wallace-Hadrill (2008). But what is gained and lost by calling this Romanization or globalization or something else? It is clear that the higher-level observations are helpful for change over time, and we shall see how this compensates for weaknesses in other theories. However, the necessary bundling and generalizing of observation understates unique interactions, never repeated in quite the same way, and across different cognitive registers. In other words, the meta-theoretical standpoint is better at describing change at the macro level than at the micro level.

In Miguel John Versluys's account (2014, 7), one key reason to adopt globalization was the hope that it would lead to taking material culture more seriously, to focus on objects within a world of heightened connectivity: 'It is now time for the Romanization debate to become genuinely archaeological and, therefore, to make material culture, with its agency and material properties, central to the analyses'. At the heart of this claim is the argument for a turn from territories towards networks, and for giving objects an important role within the networks. Astrid Van Oyen (2016a), for instance, was able to show how the emphasis on the agency of objects opens up new ways of understanding the contribution of terra sigillata (of which the above-mentioned Samian ware is a subset) in cultural and economic terms.

Moreover, in many versions of the globalization argument, there is an emphasis on returning to what Bruno Latour $(2008,173)$ calls making the global local, that is to say, finding the 'continuous connections leading from one local interaction to other places, times, and agencies through which a local site is made to do something'. Whatever the use of a rebooted Romanization thesis, or a new globalization framework might be, Latour's critique, and perhaps much of the drive even within globalization for theoretical refinement, takes us from the grand theory back to the networks themselves. In the last section, I want to restore to Witcher's global countryside a more active notion of networks, and to ask how this looks not in the middle or far distance of Rome's reach, but on her very doorstep. My contention is that this avoids exaggerating the dualism between city and countryside; and that it places emphasis on specific social practices, thus compensating for the grand scale of globalization. 


\section{Nets, Meshes, Crowds, and Fictions}

Network theory's utility for archaeology is now firmly established (Knappett 2011; 2013). A genealogy of the development of this field of study is far beyond the scope of this essay, but we can isolate some of the key steps as background to our further discussion. ${ }^{17}$ To do this I propose a highly schematic differentiation between a technical and a philosophical understanding of networks, and within the latter, the interconnected issues of object-oriented ontology and multi-scalar analysis.

Much network analysis is highly technical and derives from formal definitions and graphic representations, where the capacity to gather and sort large quantities of data can then reveal patterns. At its most basic, such representations emphasize, for instance, the movement of goods or people rather than points of deposition; nodes and lines rather than dots on a map. The philosophical implication is the emphasis on relationality, that an object or person needs to be understood in its relationships, with time, space, and other objects and persons (Van Oyen 2016b). That becomes more innovative as a notion when data permits the true richness of such relationships to be understood, and because it deposes an entirely egocentric notion of action in favour of an emphasis on our dependencies.

The next critical step in this more philosophical positioning relates to the role of objects. Emphasizing the agency of objects and human entanglement with materiality raises the significance of the material record from being simply a product of human activity to an integral and symmetrical agent (Olsen and Witmore 2015). Importantly, this enriches our understanding of what it is, and was, to be human; as Greg Woolf $(2017,216)$ puts it, 'Taking things seriously allows us to put people in perspective'.

The relational and object-oriented aspects of network theory are often regarded as a key advantage of network theory's potential in permitting analysis that operates up and down the scales of analysis, from macro to microscale and back. This itself can be seen both in the more traditional sense of microhistory, in which the emphasis is on the normally invisible actors in society, and in a more economic notion of the microscale, looking at local interactions and changes. The aspiration is to be able to see how small-scale interactions are shaped by and contribute to the broadest understanding

17 For some important recent accounts see Brughmans, Collar, and Coward (2016); Van Oyen and Pitts 2017. of social and historic change, and to create a generously inclusive analysis.

One of the larger challenges however is finding datasets which are large and rich enough to permit us to take full advantage of all these aspects, to create both a proper analysis, and to have sufficient and sufficiently diverse kinds of evidence to contextualize results and to compare and contrast. I hope to have shown even in the brief summary in the section 'Macrohistory' that the hinterland of Rome does offer precisely such richness.

At least three key advantages of looking at Latium from a network perspective seem to offer themselves. First, the concentration on nodes outside Rome offers a welcome opportunity to emphasize the relevance of the suburbium. Second, the multiplicity of information offers the chance to operate across different objects and agents. Third, although there is no doubt some value in using network theory for an early period, for seeing the emergence of a network, the value of a rich and relatively stable period is that it offers a very comprehensive dataset. Whether this constitutes good big data is arguable, but it might come close.

That said, the very richness of the data may reveal some of the limitations of some of the varieties of network thinking. One question might be how to remain aware of the gaps in the information. Notwithstanding the richness of the material, there is still a black-box effect - we see what we can trace, but we are still often seeing archaeological material at the end of its journey, which will most often not be the end of the human interaction that formed it. ${ }^{18}$

It is partly in response to these problems that Peregrine Horden (2014) developed Tim Ingold's (2007) notion of meshwork rather than network in an important essay specifically on the suburbium (cf. Grey and others 2015). Aspects of this essay which are especially relevant here include the emphasis on the non-urban as the natural state of affairs, not the urban. Throughout this essay, we have been in and out of towns, on roads, in rural sanctuaries, exploring the productive countryside. Indeed some of our towns are barely that, and certainly none is even close in size and complexity to Rome. The metaphor of the mesh is more inclusive, it leaves less out. Indeed Horden's use of the mesh edges a little towards an even more generous vision than that of Ingold, who originated the term. Ingold spoke of lines and their convolution; in a landscape con-

18 Sindbæk 2013 discusses the problems of both big data and black boxes. 
text we should surely not just look along the line but also to either side, and above and below. At any point one is surrounded conceptually by past and future, and spatially by what one passes through. It is entirely relevant that from the top of the Temple of Fortuna at Praeneste one could see the sea and that from the sea you could see the fire on the top of the temple.

So the metaphor of mesh is doing important work in pushing us as far as possible beyond the operation of either working out a spatial model, or tracking specific objects from one place to another, or even combining these; it is neither just about space, nor just about material culture. It encourages a more dynamic and a more imaginative model.

This methodological discourse is in dialogue with Latour's account of Actor-Network Theory (ANT) (Latour 2008). ANT offers two ideas to explore further. First, the notion that there is a problem to be solved or analysed is to be abandoned; rather we see the possibility of adding further descriptive layers. We can therefore envisage a research agenda which is primarily descriptive, and each description makes our mesh more complex but also more convincing. Second, the theory obliges us to take seriously what the actors said about their relationships, and this it seems to me is one way of giving real weight to the more discursive aspects of life, for instance religious networks. These were in a sense ways of describing interrelationships - they are part of a communicative process. ${ }^{19}$

Where ANT is less successful, perhaps, is in seeing the possibility for change. Rightly or wrongly, Latourian actants have been portrayed as either static or impossibly short lived, since any change in their network of relationships changes them fundamentally (Harman 2009, 104). For this reason, some modern geographers look to Manuel Delanda's Deleuzian notion of assemblages..$^{20}$ Both ANT and assemblages describe temporally vulnerable, indeed evanescent, arrangements of humans and objects in space, but scholars who work with assemblages place more emphasis on change and potentiality. In other words, it is not only the actual relationships which matter, but the potential relationships too; every assemblage is necessarily open to change. The 'connective verve' (Dewsbury 2011, 150) which characterizes participants in agencement is open to the possibility of change, but also failure. At least heuristically, it is an encouragement to recognize

19 Rüpke 2015 for religion as communication. I hope to illustrate this further for Latium in the future.

20 In French, agencement, Phillips 2006; see McFarlane 2011a; 2011b; De Munck 2017; Delanda 2006; 2016. the contingency and surprise inherent in the kinds of stability we are witnessing at one level in early imperial Latium.

Romanization and globalization are in search of a set of criteria which can be used to track macro-level change over large spaces and long tracts of time; they seek to bundle large datasets and therefore lose definition at a smaller scale. Actor-network and assemblage theories are valuable at a micro level because they focus on description. They give a more fine-grained sense of the work (both coercive and consensual) required to come close to maintaining equilibrium, but are less suited to describing longterm processes. Whilst the grand theory needs to generalize, and therefore produces the urban (or the countryside) as a type, the notion of assemblage precisely asks 'At what point does the sprawling and imaginary concept of the urban temporarily solidify into the experience of a city?' (Legg 2011, 132). My argument here is that this solidification may happen in Latium anywhere from the way station or the sanctuary right up to the gates of Rome.

It will be obvious that I am tending towards the suggestion that we need to try to work on both theoretical levels, recognizing the different strengths and weaknesses of each approach. For Latium, it might be argued that what we see is in fact the traces of the attempt to sustain the close connection of the urban to rural network, to maintain the narrowness of the difference. Imitation of urban luxury, reproduction of Roman structures in Latin towns, and the interaction of local and city elites are all visible in the epigraphic record. Networks are hard work; and for assemblages to make sense, to be coherent, it requires extraordinary levels of curation. While macro-scale analysis may address extent and largescale change over time, and are most especially helpful with the emergence of intensified settlement, and its collapse, some hybrid of ANT and assemblage theory gets us closer to the texture of the lived experience of urban and quasi-urban life, of the opportunities afforded by 'urbanity'.

To pick up another of Horden's (2014) points, whilst acknowledging the significantly unique aspects of Rome as the imperial centre, he shows that many of the qualities which we take to be urban can be seen in microcosm right through the region. 'Stable infrastructure, supervision of weights and measures, security $[\ldots]$ could all be found outside the city, not only in small towns but in the countryside too. This is consonant with Nicholas Purcell's (1998) earlier account of the evolution of the façade maritime. By focusing on issues of ecological control, mythical invention, and cultural performance, Purcell shows that the coastal region of Latium cannot be separated 
from the economics, politics, and society of Rome itself. Purcell describes how 'a whole landscape functioned allusively as a setting for otium'. And we can add so many more examples, from the Versailles-style vineyard operation at Villa Magna and the pleasure boats of Lake Nemi, to the nymphaeum at Segni, which preserves the name of its Greek architect in a shell mosaic (Fentress and others 2017; Coarelli and Ghini 2013; Cifarelli 1995; Zevi 1996).

As Purcell stresses, otium here is not trivial. It speaks directly to self-perception and self-promotion. It is a form of cultural performance which insofar as it is the reverse of negotium contributes to the definition of that activity. Indeed, the whole construction of the notion of the rural, both that which starts just outside the gates of Rome and the allusive rural spaces inside the city, and of the urban, both at Rome and in imitative miniature outside, along with the carefully selected behaviours appropriate to each, are based in imitative and mutually reinforcing practices up and down the social spectrum. This is why the self-conscious literary discourses of the opposition between town and country in fact reinforce and rely upon their interpenetration and mutual comprehensibility. They are plausible alternatives; the country is not the wilderness (Braund 1989; Purcell 1998; Skoie 2006; Spencer 2006).

Michael Smith (2019) has referred to Anthony Leeds's old but important definition, in which he stated:

Any society which has in it what we commonly call 'towns' or 'cities' is in all aspects an 'urban' society, including its agricultural and extractive domains $[. .$.$] the terms 'urban' and 'rural'$ come to stand to each other not as opposites and equivalents. Rather, the inclusive term describing the whole society is 'urban' while the term 'rural' refers only to a set of specialties of an urban society characterized by being inherently linked (under any technology known) to specific geographical spaces (Leeds 1980, 6-7).

This seems to me consistent with Horden's argument, and it offers a really helpful reminder that in this sense 'urbanity' is a construction which extends far beyond the city walls. In Latium, I suggest, we see a set of ecological, political, and demographic circumstances which permitted urbanity to be unusually widely spread.

One of the more interesting theories about how to characterize the urban is that of energized crowding. Michael Smith (2019) groups the consequences of energized crowding under three headings: scalar stress, community formation, and economic growth. Archaeologically, we lack abundant evidence for the former. Kristian Killgrove's and Wim Jongman's work on skeletal remains is a start which may in due course permit us to make more substantial arguments about the health of the population, though initial findings seem to suggest that this is a period where the population is not especially healthy (Killgrove 2017; Killgrove and Tykot 2018; Jongman, Jacobs, and Goldewijk 2019). The very high concentrations of people is certainly a significant factor for the life opportunities of some, and makes the focus on civic amenities and apparent wealth all the more striking.

The evidence for community formation is significant, and as suggested above goes beyond individual communities. The constant criss-crossing lines of connection, which we have begun to track, were all ways in which the region was united through ritual, political, economic, and social practices, to use Monica Smith's (2014) vectors for structuring urban interactions. The repetition of key ideas about the past, often expressed through ritual activity, points to the commonality of expectation and experience. An absolute key issue is the extent to which so-called towns in Latium were population centres or hubs for markets, amenities, and spectacle, and how this changes over time. Sites may show much greater discontinuity even over this relatively stable period, but that may reflect functional change. The continuity of municipal life evidenced by epigraphy suggests that even if this was somewhat fictional, it was a fiction worth preserving, and it must rest on shared perceptions of communal values, encouraged from time to time by imperial interventions.

In dialogue with the sustaining of notional communities is the maintenance of the central Italian economy. Arguments over whether the economy grows, and along what definition of growth, are complex, but current accounts tend to be positively inclined to accepting this (Erdkamp and Verboven 2015; Haas 2017; Jongman 2017). At the very least it is impossible to deny the complexity and the success of the Latin economy, even if that came at a huge price, for slaves and the marginalized. The sharing, matching, and learning behaviours which led to agglomerative economies may have been possessed also by some of the less privileged in society, especially freedmen and freedwomen, but that does not diminish the hideous inequality inherent in this system.

Moreover, these sharing, matching, and learning behaviours should not be confined to the economic. They are equally operative in cultural activities. A good example, which could be traced over the period, is in individual religious experiences, including mystery religions and so forth. The evidence of the inventive pagan cultic activity, or the spread of 
Mithraea in Latium outside Rome and Ostia, some of them in relatively small centres, ${ }^{21}$ and subsequently Christianity, might be interpreted in precisely this way. At least some of these may be eschatological responses to the inequality we have just referred to.

Insofar as energized crowding is helpful for understanding urbanization, it is not confined to the urban as defined in a traditional sense. The intense connectivity of Latium suggests that a large proportion of its dense population was behaving like an energized crowd, and across even more vectors than the model currently allows for. Both Smith and Horden cite Fernand Braudel's image of the city as an electric transformer (Braudel 1982, 479), and in a sense both are looking in very different ways at what are the inputs and outputs which would make this metaphor work, an essential aspect of being able to track long-term change. Horden's reluctance to embrace this metaphor takes him closer to Latour's insistence that it is the interrelationships between agents and agents, and agents and objects which are doing the work (working the net, spinning the mesh).

The extent of available material will in due course allow us to come closer to constructing chaîne opératoires across a variety of technological practices, to begin to assess the variety of material culture available in different kinds of locations, from towns to villas to minor centres, and perhaps even to start to think about how this material culture shaped and acted upon individual lived experience. Moreover, we can build from local interactions, to subregions and then to the regional scale, and in an area crucially connected to and reflective of the developed Roman economy. This offers an unusually rich opportunity to test our capacity to build multi-scalar but interconnected levels of description.

In short, Latium offers extraordinary opportunities for fine-grained analysis and for the descrip-

21 See, for instance, Vermaseren 1982 for the Mithraeum at Marino in the Alban Hills. tion of an array of meshes or networks, which add up to a repetitive distributed pattern. The relationships we have described, and more that we have not, construct urban life, or urbanity, right across the region; the affordances of the urban are extraordinarily widely spread.

From the Late Republic on, we see community building, economic agglomeration, scalar stress, mythical invention, and high levels of connectivity, all of which offer opportunities and challenges, which are in turn generative of innovation and adaptation, perhaps even of 'connective verve'. They are equally dependent on and productive of marginalization, inequality, and exploitation (a connection or an assemblage may be, after all, profoundly, damagingly unequal). My contention is that although this will vary in degrees across the region, the more important and salient fact is the extent to which this experience is shared. My second contention is that the opportunities and consequential downsides outlined here, however much they were inevitably influenced by the presence of Rome as a metropolis of extraordinary economic, cultural, social, and political weight, are actively co-produced by actants, to use the Latourian term to include landscape, material culture, and humans, right across Latium.

It is this meshwork which constrained and inspired at every level — physical, economic, intellectual, emotional - the lived experience of the inhabitants of Latium. We glimpse here more fully than almost anywhere else in the Roman world the variety of life; the bargemen of the coastal ports to the chestnut gatherers and pear growers of upland towns, the freedmen bailiffs and wet nurses, the aspirant local administrators and the absentee Roman patroni, the individual dedicatee in a rural shrine, and the holder of an artificially archaic priesthood. It is the sum of their actions, through and alongside their material and spatial context, which constituted Latium's connected ecology from hamlet to megalopolis (Horden and Purcell 2000, 104). 


\section{Works Cited}

Aberson, M. and others (eds). 2016. E pluribus unum? L'Italie, de la diversité préromaine à l'unité augustéenne (Bern: Lang).

Angelelli, C. 2016. 'Le Ville del suburbio di Roma tra età repubblicana e tarda antichità. Integrazioni e aggiornamenti attraverso l'analisi dei contesti pavimentali', Amoenitas, 5: 9-151.

Angelelli, C. and S. Tortorella. 2016. Per un corpus dei pavimenti di Roma e del Lazio: atti della Giornata di Studi Roma, 24 novembre 2014 Sapienza Università di Roma (Rome: Sapienza Università Editrice).

Attema, P. A. J. and T. de Haas. 2011. 'Rural Settlement and Population Extrapolation: A Case Study from the Ager of Antium, Central Italy (350 BC-AD 400)', in A. Bowman and A. Wilson (eds), Settlement, Urbanization, and Population (Oxford: Oxford University Press), pp. 97-140.

Attema, P. A. J., T. C. A. de Haas, and G. Tol. 2011. Between Satricum and Antium: Settlement Dynamics in a Coastal Landscape in Latium Vetus (Leuven: Peeters).

Becker, J. A. and N. Terrenato (eds). 2012. Roman Republican Villas: Architecture, Context, and Ideology (Ann Arbor: University of Michigan Press).

Bernard, S. 2019. 'In Search of Aeneas at the Sanctuary of Castrum Inui (Ardea)', review of M. Torelli and E. Marroni (eds), Castrum Inui: il santuario di Inuus alla foce del Fosso dell'Incastro, Academia nazionale dei Lincei, Monumenti antichi, serie miscellanea, 21 [ 76 della serie generale] (Rome: Giorgio Bretschneider Editore, 2018), Journal of Roman Archaeology, 32: 561-73<https://doi.org/10.1017/S1047759419000357>.

Bispham, E. 2007. 'Pliny the Elder's Italy', in E. Bispham, G. Rowe, and E. Matthews (eds), Vita vigilia est: Essays in Honour of Barbara Levick (London: Institute of Classical Studies), pp. 41-67.

Bjur, H. and B. S. Frizell (eds). 2009. Via Tiburtina: Space, Movement and Artefacts in the Urban Landscape (Stockholm: Svenska Institutet i Rom).

Boube, J. 1985-1986. 'Un timbre amphorique de P. Veveius Papus à Sala', Bulletin d'archéologie marocaine, 16: 401-04.

Braudel, F. 1982. The Mediterranean and the Mediterranean World in the Age of Philip II (London: Fontana).

Braund, S. H. 1989. 'City and Country in Roman Satire', in S. H. Braund (ed.), Satire and Society in Ancient Rome (Exeter: Exeter University Press), pp. 23-47.

Brughmans, T., A. Collar, and F. Coward (eds). 2016. The Connected Past: Challenges to Network Studies in Archaeology and History (Oxford: Oxford University Press).

Capanna, M. C. and P. Carafa. 2019. 'I paesaggi rurali tra il Suburbio di Roma e il Latium Vetus', in A. L. Fischetti and P. A. J. Attema (eds), Alle pendici dei Colli Albani: dinamiche insediative e cultura materiale ai confini con Roma (Groningen: Groningen Archaeological Studies).

Cifarelli, F. M. 1995. 'Un ninfeo repubblicano a Segni con la firma di Q. Mutius architetto', in Tra Lazio e Campania: ricerche di storia e di topografia antica, Quaderni del Dipartimento di Scienze dell'Antichità, 16 (Naples: Arte tipografica), pp. $159-88$.

Cifarelli, F. M. and D. Nonnis. 2019. 'Il laterizio nel Lazio repubblicano (fine III sec. a.C. - inizi I sec. a.C.): fra prosopografia della produzione e contesti di impiego', in J. Bonetto, R. Volpe, and E. Bukowiecki (eds), Alle origini del laterizio romano: nascita e diffusione del mattone cotto nel Mediterraneo tra IV e I secolo a.C.: atti del II Convegno internazionale 'Laterizio', Padova, 26-28 aprile 2016 (Rome: Quasar), pp. 441-56.

Cifarelli, F. M., S. Gatti, and D. Palombi (eds). 2019. Oltre 'Roma medio repubblicana': il Lazio fra i Galli e la battaglia di Zama: atti del Convegno internazionale (Roma, 7-8-9 giugno 2017) (Rome: Quasar).

Cifarelli, F. M. and others. 2019. 'Il Segni Project. Risultati della terza campagna di ricerche', Lazio e Sabina, 12: 221-27.

Coarelli, F. 2016. I mercanti nel tempio: delo: culto, politica, commercio (Athens: Scuola Archeologica Italiana di Atene). . 2019. Statio: i luoghi dell'amministrazione nell'antica Roma (Rome: Quasar).

Coarelli, F. and G. Ghini. 2013. Caligola: la trasgressione al potere (Rome: Gangemi).

Cornell, T. J. 200o. 'The City-States in Latium', in M. H. Hansen (ed.), A Comparative Study of Thirty City-State Cultures: An Investigation Conducted by the Copenhagen Polis Centre (Copenhagen: Royal Danish Academy of Sciences and Letters), pp. 209-28.

Cornell, T. and K. Lomas (eds). 1995. Urban Society in Roman Italy (London: Routledge).

De Franceschini, M. 2005. Ville dell'Agro romano (Rome: L’Erma di Bretschneider).

De Francesco, D. 2014. Ricerche sui villaggi nel Lazio dall'età imperiale alla tarda antichità (Rome: Quasar).

De Ligt, L. 2012. Peasants, Citizens and Soldiers: Studies in the Demographic History of Roman Italy 225 BC-AD 100 (Cambridge: Cambridge University Press).

De Ligt, L. and L.E. Tacoma. 2016. Migration and Mobility in the Early Roman Empire (Cambridge: Cambridge University Press).

De Munck, B. 2017. 'Re-assembling Actor-Network Theory and Urban History', Urban History, 44: 111-22 <https://doi. org/10.1017/So963926816000298>.

De Sena, E. C. (2005). 'An Assessment of Wine and Oil Production in Rome's Hinterland: Ceramic, Literary, Art Historical and Modern Evidence', in B. S. Frizell and A. Klynne (eds), Roman Villas around the Urbs: Interaction with Landscape and 
Environment: Proceedings of a Conference at the Swedish Institute in Rome, 17-18 September 2004 (Rome: Swedish Institute), pp. $135-49$.

Delanda, M. 2006. A New Philosophy of Society: Assemblage Theory and Social Complexity (New York: Continuum).

- 2016. Assemblage Theory (Edinburgh: Edinburgh University Press).

Dewsbury, J. D. 2011. 'The Deleuze-Guattarian Assemblage: Plastic Habits', Area, 43: 148-53.

Di Fazio, M. 2006. Fondi ed il suo territorio in età romana: profilo di storia economica e sociale (Oxford: Archaeopress).

Erdkamp, P. 2001. 'Beyond the Limits of the "Consumer City": A Model of the Urban and Rural Economy in the Roman

World', Historia, 50: 332-56.

- 2013. The Cambridge Companion to Ancient Rome (Cambridge: Cambridge University Press).

Erdkamp P. and K. Verboven (eds). 2015. Structure and Performance in the Roman Economy: Models, Methods and Case Studies (Leuven: Peeters).

Fentress, E. and others. 2017. Villa Magna: An Imperial Estate and its Legacies Excavations, 2006-10 (London: British School at Rome).

France, J. and J. Nelis-Clément. 2014. La statio archéologie d'un lieu de pouvoir dans l'empire romain (Bordeaux: Ausonius).

Frayn, J. M. 1993. Markets and Fairs in Roman Italy: Their Social and Economic Importance from the Second Century BC to the Third Century $A D$ (Oxford: Clarendon).

Frezza, G. 2012. 'I ponti nell'Italia centro-meridionale attraverso la documentazione epigrafica di età romana', Rivista storica dell'antichità, 42: 221-64.

Frizell, B. S. and A. Klynne (eds). 2005. Roman Villas around the Urbs: Interaction with Landscape and Environment: Proceedings of a Conference at the Swedish Institute in Rome, 17-18 September 2004 (Rome: Swedish Institute).

Graham, S. 2006a. Ex figlinis: The Network Dynamics of the Tiber Valley Brick Industry in the Hinterland of Rome (Oxford: British Archaeological Reports).

- 2006b. 'Networks, Agent-Based Models and the Antonine Itineraries: Implications for Roman Archaeology', Journal of Mediterranean Archaeology, 19: 45-64 <https://doi.org/10.1558/jmea.2006.19.1.45>.

Grey, C. and others. 2015. 'Familiarity, Repetition, and Quotidian Movement in Roman Tuscany', Journal of Mediterranean Archaeology, 28: 195-219.

Haas, T. de. 2017. 'The Geography of Roman Italy and its Implications for the Development of Rural Economies', in T. de Haas and G. Tol (eds), The Economic Integration of Roman Italy: Rural Communities in a Globalizing World (Leiden: Brill), pp. 51-82.

Harman, G. 2009. Prince of Networks: Bruno Latour and Metaphysics (Prahran: Re.press).

Hasenohr, C. 2007. 'Les Italiens à Délos: entre romanité et hellénisme', Pallas, 73: 221-32.

Hesnard, A. 2012. 'Lépave la Madrague de Giens (Var) et la plaine de Fondi (Latium). Producteurs des vins, des amphores

Dr 1 b et commerçants', Archaeonautica, 17: 71-93.

Hodos, T. 2017. The Routledge Handbook of Archaeology and Globalization (London: Routledge).

Holleran, C. and A. Claridge (eds). 2018. A Companion to the City of Rome (Malden: Wiley-Blackwell).

Horden, P. 2014. 'Meshwork: Towards a Historical Ecology of Mediterranean Cities', in F. Frediani (ed.), The Mediterranean Cities between Myth and Reality (Lugano: Nerbini), pp. 37-51 (repr. in P. Horden and N. Purcell, 2020, The Boundless Sea: Writing Mediterranean History (Abingdon: Routledge), no. 5).

Horden, P. and N. Purcell. 200o. The Corrupting Sea: A Study of Mediterranean History (Malden: Wiley-Blackwell). Ingold, T. 2007. Lines: A Brief History (London: Routledge).

Isayev, E. 2017. Migration, Mobility and Place in Ancient Italy (Cambridge: Cambridge University Press).

Jongman, W. 2017. 'The Benefits of Market Integration: Five Centuries of Prosperity in Roman Italy', in T. de Haas and G. Tol (eds), The Economic Integration of Roman Italy: Rural Communities in a Globalizing World (Leiden: Brill), pp. 15-27.

Jongman, W. M., J. P. Jacobs, and G. M. K. Goldewijk. 2019. 'Health and Wealth in the Roman Empire', Economics and Human Biology, 34 (2019): 138-50.

Kay, P. 2014. Rome's Economic Revolution (Oxford: Oxford University Press).

Keay, S. J. and M. Millett. 2016. 'Republican and Early Imperial Towns in the Tiber Valley', in A. Cooley (ed.), A Companion to Roman Italy (Malden: Wiley-Blackwell), pp. 355-77.

Keay, S. J. and N. Terrenato. 2001. Italy and the West: Comparative Issues in Romanization (Oxford: Oxbow).

Killgrove, K. 2017. 'Imperialism and Physiological Stress in Rome, First to Third Centuries AD', in M. S. Murphy and

D. K. Haagen (eds), Colonized Bodies, Worlds Transformed: Toward a Global Bioarchaeology of Contact and Colonialism (Gainesville: University Press of Florida), pp. 247-77.

Killgrove, K. and R. H. Tykot. 2018. 'Diet and Collapse: A Stable Isotope Study of Imperial-Era Gabii (1st-3rd Centuries AD)', Journal of Archaeological Science: Reports, 19: 1041-49 <https://doi.org/10.1016/j.jasrep.2017.05.054>.

Knappett, C. 2011. An Archaeology of Interaction: Network Perspectives on Material Culture and Society (Oxford: Oxford University Press). 
- 2013. Network Analysis in Archaeology: New Approaches to Regional Interaction (Oxford: Oxford University Press).

Lafon, X. 2001. Villa maritima: recherches sur les villas littorales de l'Italie Romaine (III siècle av. J.-C. / III siècle ap. J.-C.) (Rome: École française).

Latour, B. 2008. Reassembling the Social: An Introduction to Actor-Network-Theory (Oxford: Oxford University Press).

Laurence, R. 2011. The Roads of Roman Italy: Mobility and Cultural Change (London: Routledge).

Leeds, A. 1980. 'Towns and Villages in Society: Hierarchies of Order and Cause', in T. Collins (ed.), Cities in a Larger Context

(Athens: University of Georgia Press), pp. 6-33.

Legg, S. 2011. 'Assemblage/Apparatus: Using Deleuze and Foucault', Area, 43: 128-33.

Marzano, A. 2007. Roman Villas in Central Italy: A Social and Economic History (Leiden: Brill).

- 2013a. 'Agricultural Production in the Hinterland of Rome: Wine and Olive Oil', in A. K. Bowman and A. I. Wilson

(eds), The Roman Agricultural Economy: Organisation, Investment and Production (Oxford: Oxford University Press), pp. 85-106.

- 2013b. Harvesting the Sea: The Exploitation of Marine Resources in the Roman Mediterranean (Oxford: Oxford University Press).

Marzano, A. and G. P. R. Métraux. 2018. The Roman Villa in the Mediterranean Basin: Late Republic to Late Antiquity

(Cambridge: Cambridge University Press).

McFarlane, C. 2011a. 'Assemblage and Critical Urbanism', City, 15: 204-24 <https://doi.org/10.1080/13604813.2011.568715>.

- 2011b. 'The City as Assemblage: Dwelling and Urban Space', Environment and Planning D: Society and Space, 29: 649-71 $<$ https://doi.org/10.1068/d4710>.

Moggetta, M. 2014. 'Latium Vetus, Latium Adjectum', in C. Smith (ed.), Encyclopedia of Global Archaeology (New York: Springer), pp. 4450-59.

Morley, N. 1996. Metropolis and Hinterland: The City of Rome and the Italian Economy, $200 \mathrm{BC}-\mathrm{AD} 200$ (Cambridge: Cambridge University Press).

Olsen, B. and C. Witmore. 2015. 'Archaeology, Symmetry, and the Ontology of Things: A Response to Critics', Archaeological Dialogues, 22: 187-97.

Patterson, H., H. di Giuseppe, and R. Witcher. Forthcoming. The Changing Landscapes of Rome's Northern Hinterland: The British School at Rome's Tiber Valley Project (Oxford: Archaeopress).

Pelgrom, J. 2013. 'Population Density in Mid-Republican Latin Colonies: A Comparison between Text-Based Population Estimates and the Results from Survey Archaeology', Atlante tematico di topografia antica, 23: 73-84.

Phillips, J. 2006. 'Agencement/Assemblage', Theory, Culture and Society, 23.2-3: 108-09 <https://doi.org/10.1177/0263276406 02300219>.

Pitts, M. and M. J. Versluys. 2015. Globalisation and the Roman World: World History, Connectivity and Material Culture (Cambridge: Cambridge University Press).

Potter, T. W. 1979. The Changing Landscape of South Etruria (London: Elek).

Purcell, N. 1996. 'Rome and the Management of Water: Environment, Culture and Power', in G. Shipley and J. B. Salmon (eds), Human Landscapes in Classical Antiquity: Environment and Culture (London: Routledge), pp. 180-212.

- 1998. 'Alla scoperta di una costa residenziale romana: il litus Laurentinum e l'archeologia dell'otium', in M. G. Lauro (ed.), Castelporziano, III: Campagne di scavo e restauro, 1987-1991 (Rome: Viella), pp. 11-32.

Quilici, L. 1991. Le strade: viabilitá tra Roma e Lazio (Rome: Quasar).

Rüpke, J. 2015. 'Religious Agency, Identity, and Communication: Reflections on History and Theory of Religion', Religion, 45: 344-66 <https://doi.org/10.1080/0048721X.2015.1024040>.

Russell, B. 2013. The Economics of the Roman Stone Trade (Oxford: Oxford University Press).

Salomies, O. 1996. 'Senatori oriundi del Lazio', in H. Solin (ed.), Studi storico-epigrafici sul Lazio Antico, Acta Instituti Romani Finlandiae (Rome: Instituti Romani Finlandiae), pp. 23-127.

Sindbæk, S. M. 2013. 'Broken Links and Black Boxes: Material Affiliations and Contextual Network Synthesis in the Viking World', in C. Knappett (ed.), Network Analysis in Archaeology: New Approaches to Regional Interaction (Oxford: Oxford University Press), pp. 71-94.

Skoie, M. 2006. 'City and Countryside in Vergil's Eclogues', in R. Rosen and I. Sluiter (eds), City, Countryside, and the Spatial Organization of Value in Classical Antiquity (Leiden: Brill), pp. 297-326.

Smith, M. E. 2019. 'Energized Crowding and the Generative Role of Settlement Aggregation and Urbanization', in A. Gyucha (ed.), Coming Together: Comparative Approaches to Population Aggregation and Early Urbanization, Institute for European and Mediterranean Archaeology Proceedings, 8 (New York: State University of New York Press), pp. $37-58$.

Smith, M. L. 2014. 'The Archaeology of Urban Landscapes', Annual Review of Anthropology, 43.1: 307-23 <https://doi. org/10.1146/annurev-anthro-102313-025839>.

Solin, H. 1996. 'Sul concetto di Lazio nell'antichità, in H. Solin (ed.), Studi storico-epigrafici sul Lazio Antico, Acta Instituti Romani Finlandiae (Rome: Instituti Romani Finlandiae), pp. 1-22. 
Spencer, D. 2006. 'Horace's Garden Thoughts: Rural Retreats and the Urban Imagination', in R. Rosen and I. Sluiter (eds), City, Countryside, and the Spatial Organization of Value in Classical Antiquity (Leiden: Brill), pp. 239-74.

Storchi Marino, A. 2000. 'Reti interregionali integrate e circuiti di mercato periodico negli indices nundinarii del Lazio e della Campania', in E. Lo Cascio (ed.), Mercati permanenti e mercati periodici nel mondo romano: atti degli incontri capresi di storia dell'economia antica (Capri 13-15 ottobre 1997) (Bari: Edipuglia), pp. 93-130.

Tacoma, L. E. 2016. Moving Romans: Migration to Rome in the Principate (Cambridge: Cambridge University Press).

Talbert, R. J. A. 2008. 'Greek and Roman Mapping: Twenty-First Century Perspectives', in R. J. A. Talbert and R. W. Unger (eds), Cartography in Antiquity and the Middle Ages: Fresh Perspectives, New Methods (Leiden: Brill), pp. 9-27.

Tchernia, A. 1986. Le vin de l'Italie romaine: essai d'histoire économique d'après les amphores (Rome: École française).

Temin, P. 2012. The Roman Market Economy (Princeton: Princeton University Press).

Terrenato, N. 2019. The Early Roman Expansion into Italy: Elite Negotiation and Family Agendas (Cambridge: Cambridge University Press).

Thomas, R. and A. Wilson. 1994. 'Water Supply for Roman Farms in Latium and South Etruria', Papers of the British School at Rome, 62: 139-96.

Tol, G., T. de Haas, and C. Anastasia. 2019. 'Il ruolo dei centri minori nell'economia romana: una panoramica dei risultati delle indagini archeologiche nei siti di Forum Appii ed Ad Medias', in A. Fischetti and P. A. J. Attema (eds), Alle pendici dei Colli Albani: dinamiche insediative e cultura materiale ai confini con Roma, Groningen Archaeological Studies, 35 (Eelde: Barkhuis), pp. 29-42.

Tol, G. and others. 2014. 'Minor Centres in the Pontine Plain: The Cases of Forum Appii and Ad Medias', Papers of the British School at Rome, 82: 109-34 <https://doi.org/10.1017/Soo68246214000063>.

Van Oyen, A. 2016a. How Things Make History: The Roman Empire and its Terra Sigillata Pottery (Amsterdam: Amsterdam University Press).

- 2016b. 'Historicising Material Agency: From Relations to Relational Constellations', Journal of Archaeological Method and Theory, 23: 354-78.

Van Oyen, A. and M. Pitts (eds). 2017. Materialising Roman Histories (Oxford: Oxbow).

Veal, R. 2013. 'Fuelling Ancient Mediterranean Cities: A Framework for Charcoal Research', in W. V. Harris (ed.), The Ancient Mediterranean Environment between Science and History (Leiden: Brill), pp. 37-58.

- 2017. 'Wood and Charcoal for Rome: Towards an Understanding of Ancient Regional Fuel Economics', in T. de Haas and G. Tol (eds), The Economic Integration of Roman Italy: Rural Communities in a Globalizing World (Leiden: Brill), pp. 388-406.

Venditti, C. P. 2011. Le villae del Latium adiectum: aspetti residenziali delle proprietà rurali (Bologna: Ante Quem).

Vermaseren, M. J. 1982. Mithriaca, III: The Mithraeum at Marino (Leiden: Brill).

Versluys, M. J. 2014. 'Understanding Objects in Motion: An Archaeological Dialogue on Romanization', Archaeological Dialogues, 21: 1-20 <https://doi.org/10.1017/S1380203814000038>.

Wallace-Hadrill, A. 2008. Rome's Cultural Revolution (Cambridge: Cambridge University Press).

Wilson, A. I. 2009. 'Villas, Horticulture and Irrigation Infrastructure in the Tiber Valley', in F. Coarelli and H. Patterson (eds), Mercator Placidissimus: The Tiber Valley in Antiquity: New Research in the Upper and Middle River Valley: Proceedings of the Conference Held at the British School at Rome, 27-28 Feb. 2004 (Rome: Quasar), pp. 731-68.

Witcher, R. 2005. 'The Extended Metropolis: Urbs, Suburbium and Population', Journal of Roman Archaeology, 18.1: 120-38.

- 2008. 'Regional Field Survey and the Demography of Roman Italy', in L. de Ligt and S. Northwood (eds), People, Land and Politics: Demographic Developments and the Transformation of Roman Italy, 300 BC-AD 14 (Leiden: Brill), pp. $273-303$.

- 2017. 'The Global Roman Countryside: Connectivity and Community', in T. de Haas and G. Tol (eds), The Economic Integration of Roman Italy: Rural Communities in a Globalizing World (Leiden: Brill), pp. 28-50.

Woods, M. 2007. 'Engaging the Global Countryside: Globalization, Hybridity and the Reconstitution of Rural Place', Progress in Human Geography, 31: 485-507 <https://doi.org/10.1177/0309132507079503>.

—. 2009. 'Rural Geography: Blurring Boundaries and Making Connections', Progress in Human Geography, 33: 849-58 $<$ https://doi.org/10.1177/0309132508105001>.

Woolf, G. 1992. 'Imperialism, Empire and the Integration of the Roman Economy', World Archaeology, 23: 283-93.

- 2017. 'Roman Things and Roman People: A Cultural Ecology of the Roman World', in A. Van Oyen and M. Pitts (eds), Materialising Roman Histories (Oxford: Oxbow), pp. 211-16.

Zevi, F. 1996. 'Les élites municipali, Mario e l'architettura del tempo', Cahiers du Centre Gustave Glotz, 7: 229-52. 
